\title{
Slow arm regeneration in the Antarctic brittle star Ophiura crassa (Echinodermata, Ophiuroidea)
}

\author{
Melody S. Clark*, Terri Souster
}

British Antarctic Survey, Natural Environment Research Council, High Cross, Madingley Road, Cambridge CB3 0ET, UK

\begin{abstract}
Regeneration of arms in brittle stars is thought to proceed slowly in low temperature environments. Here a survey of natural arm damage and arm regeneration rates is documented in the Antarctic brittle star Ophiura crassa. This relatively small ophiuroid, a detritivore found amongst red macroalgae, displays high levels of natural arm damage and repair. This is largely thought to be due to ice damage in the shallow waters it inhabits. The time scale of arm regeneration was measured in an aquarium-based 10 mo experiment. There was a delayed regeneration phase of 7 mo before arm growth was detectable in this species. This is 2 mo longer than the longest time previously described, which was in another Antarctic ophiuroid, Ophionotus victoriae. The subsequent regeneration of arms in $O$. crassa occurred at a rate of approximately $0.16 \mathrm{~mm} \mathrm{mo}^{-1}$. To date, this is the slowest regeneration rate known of any ophiuroid. The confirmation that such a long delay before arm regeneration occurs in a second Antarctic species provides strong evidence that this phenomenon is yet another characteristic feature of Southern Ocean species, along with deferred maturity, slowed growth and development rates. It is unclear whether delayed initial regeneration phases are adaptations to, or limitations of, low temperature environments.
\end{abstract}

KEY WORDS: Ophiura crassa · Ophionotus victoriae · Autoecology · Ophioderma longicaudum • Brooder $\cdot Q_{10}$ coefficient

\section{INTRODUCTION}

The Antarctic marine environment is characterised by very low, stable temperatures. The long time scale over which these conditions have existed, in tandem with the effective geographical isolation of the continent by the Antarctic circumpolar current, has produced a fauna highly adapted to these extreme conditions (Peck et al. 2006). In general, the endemic benthic species are characterised by slow physiological rates, including growth and development, deferred maturity, low metabolic rates and extended life histories (reviewed in Peck 2005). Much of our understanding about these adaptations has come from research on Echinodermata, a taxon which comprises almost $45 \%$ of the large epifauna in terms of numerical abundance and weight (Moya et al.
2003) and, hence, represents a major component of the ecosystem. Research on Antarctic members of this phylum of highly calcified invertebrates dates back to the 'Discovery' expeditions (Mortensen 1936) and has encompassed a wide range of subjects, including ecological observations (McClintock 1994, Arnaud et al. 1998), reproduction (Pearse et al. 1991, Grange et al. 2004), aging (Dahm \& Brey 1998) and regeneration (Clark et al. 2007). The latter study produced a particularly intriguing observation; the brittle star Ophionotus victoriae exhibited delayed arm regeneration in which a period of 5 mo elapsed from when the initial limb amputation occurred to when observable regenerative bud formation and regrowth was noted (Clark et al. 2007).

Histological studies have divided arm regeneration in brittle stars into 4 main phases: wound repair with 
re-epithelialisation; early regeneration with complete healing and cell proliferation at the site of damage; intermediate regeneration resulting in blastema formation; and, finally, advanced regeneration with the development of a miniature arm (Biressi et al. 2010). Based on gross morphological observations, it is production of a regenerative bud and arm elongation that constitutes the delayed phase in Ophionotus victoriae (Clark et al. 2007). Overall, the rate of regeneration was one of the slowest recorded to date for brittle stars, at $0.44 \mathrm{~mm} \mathrm{wk}^{-1}$. This led to the question of whether these phenomena of delayed initial regeneration phases and slowed re-growth were species-specific or examples of adaptation to life in the cold, or whether low water temperatures placed restrictions on regeneration.

Recently, regeneration in the temperate brittle star Ophioderma longicaudum has been described to have an even slower regeneration rate of $0.17 \mathrm{~mm}$ $\mathrm{wk}^{-1}$; although, it took only $3 \mathrm{wk}$ to initiate regeneration and generate a blastema and measureable regenerative bud (Biressi et al. 2010). Here we describe further regeneration studies on another common Antarctic brittle star, Ophiura crassa Mortensen, 1936, to further elucidate regeneration processes in ophiuroids and in particular to understand the effect of temperature.

Ophiura crassa is a small, orange-coloured brittle star, which was first described in the Discovery Reports (Mortensen 1936). Relatively little work has been carried out on this species, but it is known to be a common member of the Antarctic benthos and has a circumpolar distribution. Its depth distribution has been described between 6 and $220 \mathrm{~m}$ (McKnight 1967, Lane \& Riddle 2004, Johnston et al. 2007) and whilst it has been identified as inhabiting both hard and soft substrata, it appears to feed on fine detrital material and small sediment particles (Lane \& Riddle 2004). We carried out regeneration studies on this species that involved both a field survey and an aquarium-based arm regeneration experiment and compared the results with previous data on ophiuroids.

\section{MATERIALS AND METHODS}

\section{Brittle star collection}

Brittle stars were collected from Cheshire Island adjacent to the British Antarctic Survey Research Station at Rothera Point, Adelaide Island, West Antarctic Peninsula $\left(67^{\circ} 34.5^{\prime} \mathrm{S}, 68^{\circ} 07.0^{\prime} \mathrm{W}\right)$. The brittle stars were collected by SCUBA divers during the austral summer (January to March) at a depth of 14 to $18 \mathrm{~m}$ and were immediately taken to the laboratory where they were maintained in a flow-through aquarium containing natural seawater under a simulated light:dark cycle. During the time the brittle stars were held in the aquarium, the water temperature was generally less than $0^{\circ} \mathrm{C}$, but ranged between $-1.3^{\circ} \mathrm{C}$ in the winter to a maximum of $+1.8^{\circ} \mathrm{C}$ for brief periods at the end of February 2011 (Fig. 1). The brittle stars were kept in association with the red macroalga Phyllophora antarctica, the dominant substratum in the area where they were collected. Only brittle stars with natural arm damage were used in the survey. Arm damage caused by collection was virtually absent.

\section{Morphometric measurements}

After anaesthesia with 3\% magnesium chloride $\left(\mathrm{MgCl}_{2}\right)$ in seawater (as described in Dupont \& Thorndyke 2006), 100 brittle stars were measured for disc diameter by using vernier calipers and length of the longest undamaged arm. Each arm was also assessed for damage (presence and number of scars) and the position of the damage was noted as proximal (in the third of the arm nearest the disc), medial (in the middle third) or distal (in the distal third nearest the arm tip). These brittle stars were returned to the sea and a separate set was used for the regeneration experiments to minimise exposure to anaesthesia.

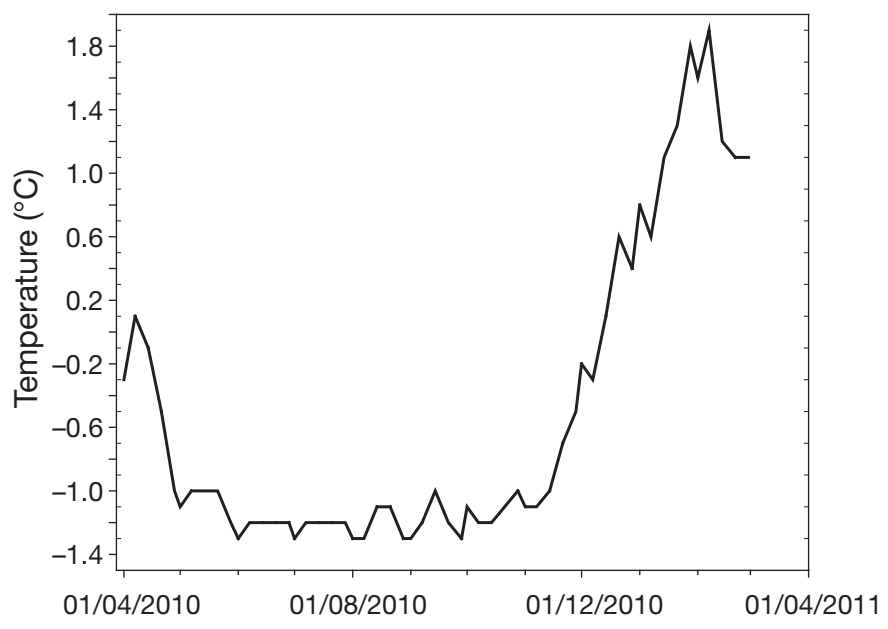

Fig. 1. Aquarium temperatures at Rothera Point base during the course of the brittle star arm regeneration experiment. Dates are $\mathrm{dd} / \mathrm{mm} /$ yyyy 


\section{Regeneration experiments}

Approximately 220 brittle stars were used for this study, starting in May 2010. Individuals were chosen that showed either minimal or no arm damage. The brittle stars were anaesthetised with $3 \% \mathrm{MgCl}_{2}$ in seawater. When movement had ceased, they were removed from the anaesthetic, and one arm was amputated from each animal at approximately the fifth segment $(2.5$ to $3.0 \mathrm{~mm})$ from the disc. They were then returned immediately to the aquarium. This was to ensure that exposure of the cut surface to the anaesthetic (and therefore putative cell damage) was kept to a minimum. Each month, over the course of 10 mo, 9 brittle stars were sampled at random from the aquarium and regeneration was assessed. Each specimen was again anaesthetised with $3 \% \mathrm{MgCl}_{2}$ in seawater, and the length of the regenerating portion of the amputated arm was viewed under a DinoLite $^{\mathrm{TM}}$ digital microscope and measurements were made with the associated software, or the brittle star was viewed under an Olympus BX50 microscope and measurements were analysed in ImageJ (http:// rsbweb.nih.gov/ij/). A random sampling technique was developed (rather than measuring all specimens each month) to minimise disturbance of the animals, avoid any potential effects of repeated anaesthesia on limb regeneration and also avoid damage from handling. The regenerated limb was amputated and stored for future molecular analyses and then the brittle stars were returned to the sea.

\section{Calculations and statistics}

Statistical analyses (normality tests [Anderson Darling]) and regressions) were performed in Minitab v15 and are fully detailed in the 'Results'.

\section{RESULTS}

\section{General biology}

At Rothera base, Antarctic Peninsula, Ophiura crassa has been observed by divers as being common between 14 to $22 \mathrm{~m}$ depth on steep slopes and associated with dense macroalgal beds; although, it has been seen at depths as shallow as $8 \mathrm{~m}$ and occasionally in rocky habitats (L. S. Peck pers. comm.) (Table 1). The brittle stars for this particular trial were collected from steep slopes off Cheshire Island, where they were found among the red macroalga Phyllophora antarctica along with many other filterfeeding animals, such as Cnemidocarpa verrucosa and Heterocucumis steinei (T. Souster pers. obs.). The animals were kept in the aquarium associated with Phyllophora antarctica, which appeared to provide the nutritional requirements for this brittle star. This was substantiated by the successful long-term culture of $O$. crassa in the aquarium (specimens have been held on this substratum for over $1 \mathrm{yr}$ with no mortality or behavioural changes). However, it was most likely that it was not the macroalga per se pro-

Table 1. Ophiura crassa and Ophionotus victoriae. Comparison of the 2 brittle star habitats and life histories. Relevant references are included below each description.

\begin{tabular}{|c|c|c|}
\hline $\begin{array}{l}\text { Habitat or life } \\
\text { history description }\end{array}$ & O. crassa & O. victoriae \\
\hline $\begin{array}{l}\text { Local distribution } \\
\text { (Rothera) }\end{array}$ & $\begin{array}{l}\text { Cheshire Island } \\
\text { T. Souster \& L. S. Peck (pers. obs.) }\end{array}$ & $\begin{array}{l}\text { South Cove and Hangar Cove } \\
\text { T. Souster \& L. S. Peck (pers. obs.) }\end{array}$ \\
\hline $\begin{array}{l}\text { Local habitat } \\
\text { substratum (Rothera) }\end{array}$ & $\begin{array}{l}\text { Steep slopes and macroalgae } \\
\text { T. Souster \& L. S. Peck (pers. obs.) }\end{array}$ & $\begin{array}{l}\text { Hard bedrock and compacted cobbles } \\
\text { often with an overlying layer of silt } \\
\text { Brown et al. (2004) }\end{array}$ \\
\hline Depth & $\begin{array}{l}6 \text { to } 220 \mathrm{~m} \\
\text { McKnight (1967), Lane \& Riddle (2004), Johnston } \\
\text { et al. (2007), T. Souster \& L. S. Peck (pers. obs.) }\end{array}$ & $\begin{array}{l}5 \text { to } 1266 \mathrm{~m} \\
\text { Madsen (1967) }\end{array}$ \\
\hline Diet & $\begin{array}{l}\text { Detritivore } \\
\text { Lane \& Riddle (2004) }\end{array}$ & $\begin{array}{l}\text { Primary scavenger } \\
\text { Fratt \& Dearborn (1984), McClintock (1994) }\end{array}$ \\
\hline Reproductive mode & $\begin{array}{l}\text { Brooder } \\
\text { T. Souster (pers. obs.) }\end{array}$ & $\begin{array}{l}\text { Broadcast spawner } \\
\text { Grange et al. (2004) }\end{array}$ \\
\hline Average disc diameter & $\begin{array}{l}6.8 \mathrm{~mm} \\
\text { (this study) }\end{array}$ & $\begin{array}{l}17.4 \text { to } 25.9 \mathrm{~mm} \text {, depending on cohort } \\
\text { Clark et al. (2007) }\end{array}$ \\
\hline
\end{tabular}


viding nutrition directly, but the microflora and microfauna on the algae. This would identify this brittle star species as a detritivore and confirm the observations of Lane \& Riddle (2004). Additional observations from a separate experiment showed that this species had a brooding reproductive mode (T. Souster pers. comm.), but the natural timing of this event and animal size at first reproduction is unknown. No juveniles were released during the course of this regeneration experiment.

\section{Natural damage}

Measurements from the natural population showed that disc diameter was weakly correlated with arm length (disc size $[\mathrm{mm}]=4.09+$ $0.0936 \cdot$ arm length [mm] with $F_{1,99}=15.50, \mathrm{p}<$ $\left.0.01, R^{2}=13.7 \%\right)$. The mean disc diameter was $6.8 \pm 0.113 \mathrm{~mm}$ (mean $\pm \mathrm{SE}$ ), and the mean size of the longest arm was $29.6 \pm 0.448 \mathrm{~mm}$ (Fig. 2A). The amount of damage in the natural population was also very weakly correlated with disc size (using disc size as a proxy of age, cf. Dahm \& Brey 1998), where the number of regenerating arms $=0.111+0.173 \times$ disc size $(\mathrm{mm})$, with $F_{1,98}=4.17, \mathrm{p}=0.04, \mathrm{R}^{2}=4.1 \%$ (Fig. 2B). Although this is significant, the $\mathrm{R}^{2}$ is only $4.1 \%$, which means that disc size has little influence on the incidence of damage. With regard to the level of natural damage and repair of the arms in each animal, $28 \%$ were completely undamaged, $39 \%$ had a single arm damaged, $18 \%$ had damage to 2 arms, $7 \%$ had 3 arms damaged, $6 \%$ had 4 arms damaged and $2 \%$ showed damage on all arms. The majority of the damage $(52 \%)$ was at the arm tip (distal to the disc), whilst $28 \%$ of the damage was medial and only $20 \%$ of the damage was close to the disc (proximal).

\section{Regeneration}

Arm regeneration was measured in the aquarium over a period of $10 \mathrm{mo}$. There was no mortality in either the experimental or control brittle stars over this period. The control animals were brought into the aquarium facilities at the same time as those for the experiment. They were kept in the same conditions, except no arm amputations were carried out. In the experimental animals there was no reproducible arm regeneration, in terms of being able to see a
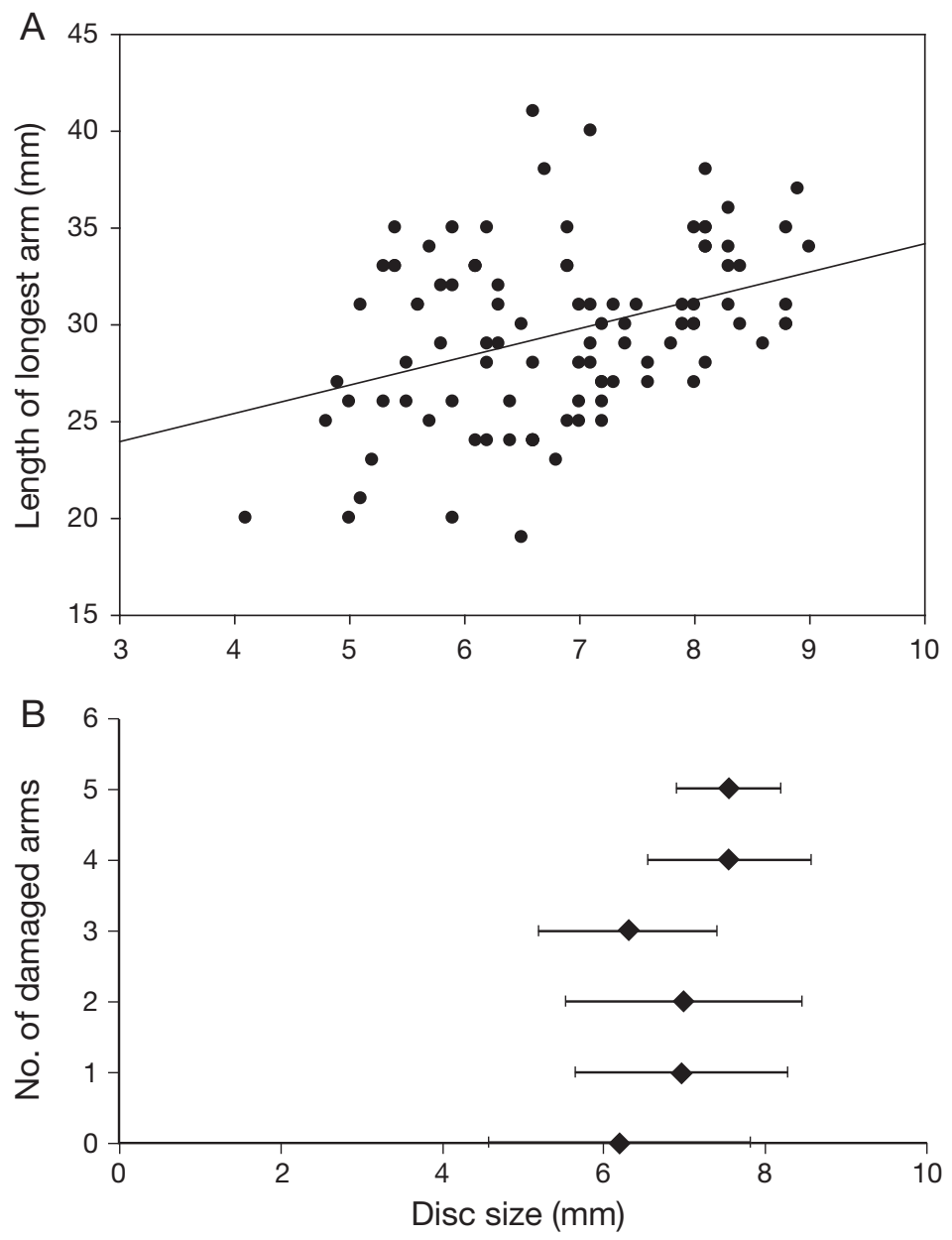

Fig. 2. Ophiura crassa. (A) Correlation between disc size and length of the longest arm. (B) Correlation between disc size and the number of arms damaged. No brittle stars showed more than one scar per arm

regenerative bud being produced, for the first $6 \mathrm{mo}$ of the study. By Month 7 all arms from the random sampling showed some measure of regeneration $(0.3692 \pm 0.048 \mathrm{~mm})$. The length of regenerating arm was plotted against time, but since the data did not show a normal distribution, the regenerating arm length values were converted to $\log _{10}$ values. These data were verified as normal (Anderson-Darling test) and then plotted against time with the relationship: $\log _{10}$ of length regenerated $(\mathrm{mm})=-1.43+0.0341 \times$ time of regeneration (wk) (Fig. 3). This equation indicated that the regenerating arm growth was approximately $0.04 \mathrm{~mm} \mathrm{wk}^{-1}$ or $0.16 \mathrm{~mm} \mathrm{mo}^{-1}$. The log:linear relationship with a positive slope indicates an increase in rate of regeneration over the period of this experiment $(0.033 \mathrm{~mm}$ at Week 28, $0.086 \mathrm{~mm}$ at Week 40). Brittle stars from each of the monthly samplings had similar disc sizes with a mean $( \pm \mathrm{SE})$ of $6.8 \pm 0.112 \mathrm{~mm}$, which is the same as the population mean and equates to an approximate full-length arm 


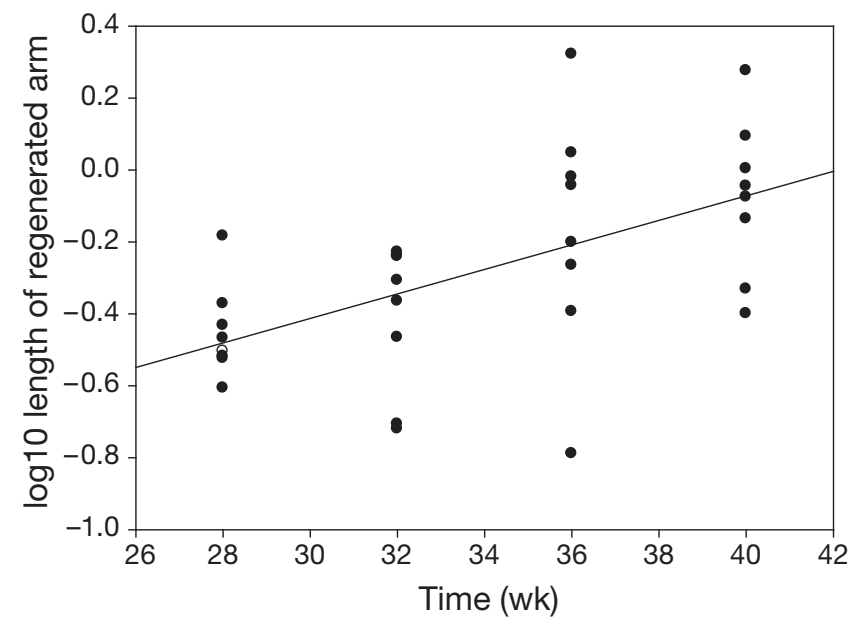

Fig. 3. Ophiura crassa. Regeneration rate of brittle star arms. Data shown only from Month 7, as this was the first month of consistently observable growth

of $29.6 \mathrm{~mm}$ for this average-sized animal. As each arm was amputated approximately 5 segments away from the disc (2.5 to $3.0 \mathrm{~mm}$ ), each animal would require almost $26 \mathrm{~mm}$ of re-growth to regenerate a full-length arm.

\section{DISCUSSION}

The study of regeneration in Ophiura crassa provides useful data that can be compared with previous information on another Antarctic ophiuroid, Ophionotus victoriae (Clark et al. 2007). Both have a circumpolar distribution and occur commonly at Rothera Point; hence, regeneration processes can be described over the same temperature range in vicinal populations of 2 related species (members of the family Ophiuridae). Despite their contrasting habits and sizes (Table 1), both species display high levels of natural arm damage with $72 \%$ of $O$. crassa individuals and $99 \%$ of $O$. victoriae individuals being affected. Although similar levels of damage have been described for some populations of temperate members of the Amphiuridae (Amphiura chajei, A. filiformis and Microphiopholis gracillima; 99.1, 86 and $85 \%$, respectively) (Munday 1993, Biressi et al. 2010, Stancyk et al. 1994), this consistently high level of damage is relatively unusual (Sköld \& Rosenberg 1996). In general, loss of arms in brittle stars is strongly associated with predation pressure from fish (cf. Bourgoin \& Guillou 1994), but this is not the case with Antarctic species. There is a distinct lack of fish predation on brittle stars (Casaux et al. 2003), so the higher percentage of damaged arms in Antarctic brittle stars is thought to be largely due to environ- mental factors, namely ice damage combined with slower growth rates and enhanced longevity (Clark et al. 2007). Ice damage is expected to significantly affect these $O$. crassa populations living at 14 to $22 \mathrm{~m}$ depth, as disturbance is related to depth and is greater at shallow depths and also at the south end of Rothera Point (Brown et al. 2004).

The lower level of arm damage in Ophiura crassa compared with Ophionotus victoriae is almost certainly related to its smaller size and potentially to a small amount of protection that is provided by the habitat. This species is associated with red macroalgae, but it is also found between rocks on the walls and so may use these as extra protection. Age may also play a factor. Whilst nothing is known of aging or the age structure of $O$. crassa, it was noticeable from the survey of natural arm damage that there were no double scars, i.e. each arm was only damaged once. In the $O$. victoriae study, age was a factor in incidence of damage: double scars only occurred in $3 \%$ of the South Cove samples, which comprised a younger cohort compared with the Hangar Cove population (15\% with double scars) (Clark et al. 2007). Hence, the much smaller O. crassa may have a shorter life span compared with $O$. victoriae, which is a broadcast spawner; there is evidence from other ophiuroids that a brooding reproductive mode is correlated with a shorter life span (Medeiros-Bergen \& Ebert 1995).

Arm regeneration was not detected in Ophiura crassa consistently in all samples until 7 mo after amputation, even with the use of a microscope. This delayed regeneration phase, which is equivalent to the production of a regenerative bud (Biressi et al. 2010), was longer than previously described in Ophionotus victoriae (5 mo) (Clark et al. 2007). It should be noted that this amputation was the result of trauma and not natural autotomy. Hence, the procedure may have caused more cellular damage than would have occurred naturally (and consequently increased the requirement for repair). However, the time scales for regeneration in this species are clearly still very long. It is interesting to note that the most productive period of arm regeneration coincided with the commencement of the austral summer and a gradual rise in aquarium temperatures (Fig. 1). Whilst it cannot be discounted that there is a seasonally entrained biorhythm (Clarke 1988) or that rising temperatures trigger regeneration, there are several reasons why this may not be so. The strongest argument against a seasonal effect is that regeneration started in some of the brittle stars in September $\left(-1.1^{\circ} \mathrm{C}\right)$ and all had started by November $\left(-1.0^{\circ} \mathrm{C}\right)$ 
with temperatures not rising above $0^{\circ} \mathrm{C}$ until mid December, which was similar to data from O. victoriae, which started to regenerate in mid winter when temperatures were well below $0^{\circ} \mathrm{C}$. Also the animals were maintained in an aquarium system, so seasonality of the marine environment would be less pronounced in terms of both food supply and light regime. So, in summary, the initial delayed regeneration phase, described in a second Antarctic species, strongly supports the argument that this is not a species-specific phenomenon, but is a general characteristic of Antarctic brittle stars. This is in line with previous studies that show markedly slowed development and growth rates of between 2 and 10 times slower in Antarctic echinoderms (Brey et al. 1995, McClintock et al. 1988) and between 5 and 10 times slower in Antarctic invertebrates in general (Peck 2005) compared with temperate counterparts.

Biological processes are dramatically affected by temperature, and $Q_{10}$ coefficients can provide a measure of the change in rates of biological processes across temperatures. Over a century of physiological research has shown that thermal dependency usually falls within a narrow range of rates, roughly doubling or tripling with each $10^{\circ} \mathrm{C}$ rise in temperature, and the overwhelming majority of processes fall within the range $Q_{10}=1$ (i.e. no change) to 4 for each $10^{\circ} \mathrm{C}$ increase. Values within this range are generally taken to show that there has been no compensation for temperature effects in the process (Clarke 1983). Values outside the range either show temperature compensation $\left(Q_{10} \leq 1.0\right)$ or that the processes are more influenced by factors other than temperature. Comparing the 7 mo (215 d) delayed regeneration phase of Ophiura crassa to that of temperate brittle stars used in the Ophionotus victoriae paper of Clark et al. (2007) produces a $Q_{10}$ of 4.8 for the most conservative estimate using Astrobrachion constrictum (1 mo to produce a regenerative bud at $12.5^{\circ} \mathrm{C}$, Stewart 1996) up to a $Q_{10}$ of 20.8 using Amphiura filiformis ( $3 \mathrm{~d}$ to develop a regenerative arm at $14^{\circ} \mathrm{C}$, Biressi et al. 2010). Even the most conservative estimate of $Q_{10}$ indicates that the initial phases of regeneration are more importantly influenced by factors other than temperature directly slowing the processes. It is currently not known why it takes so long to produce a regenerant bud in Antarctic brittle stars or indeed whether it is the retardation of wound repair, re-epithelialisation or cell proliferation that delays regeneration. These will be the subject of further studies involving molecular analyses.

The basic mechanism of arm regeneration in Ophiura crassa appears to be similar to that described in other brittle stars, including Ophionotus victoriae. An initial undifferentiated structure was followed by gradual differentiation with the development of spines and functional podia (Fig. 4) (Clark et al. 2007, Biressi et al. 2010). Initially, it was possible to consistently measure regeneration in each sample at Month 7 (mean size $=0.3692 \pm 0.0448 \mathrm{~mm}$ ), with an average regenerated length of $0.9340 \pm 0.1670 \mathrm{~mm}$ by Month 10 . However, the rate was highly variable. Taking into account the smallest measured arm regenerated and the longest length measured per monthly sampling, we observed an approximate 3-fold difference in Months 7 and 8, a 5-fold difference in Month 10 and a massive 13-fold difference in Month 9 (from 0.163 to $2.098 \mathrm{~mm}$ ). A similar situation was described in $O$. victoriae where after $1 \mathrm{yr}, 1$ individual had regenerated only $5.6 \%$ of the original length of an arm, whilst another had re-grown approximately $33 \%$ of its original length (Clark et al. 2007). Some of this variability in $O$. victoriae was due to the length of arm lost where regeneration rate increased as the length of arm lost also increased. This was not possible to accurately determine in $O$. crassa. Overall regression analyses of the data on length of arm regenerated with time produced an average rate of $0.04 \mathrm{~mm} \mathrm{wk}^{-1}$, which is much slower than any regeneration rates previously described. If

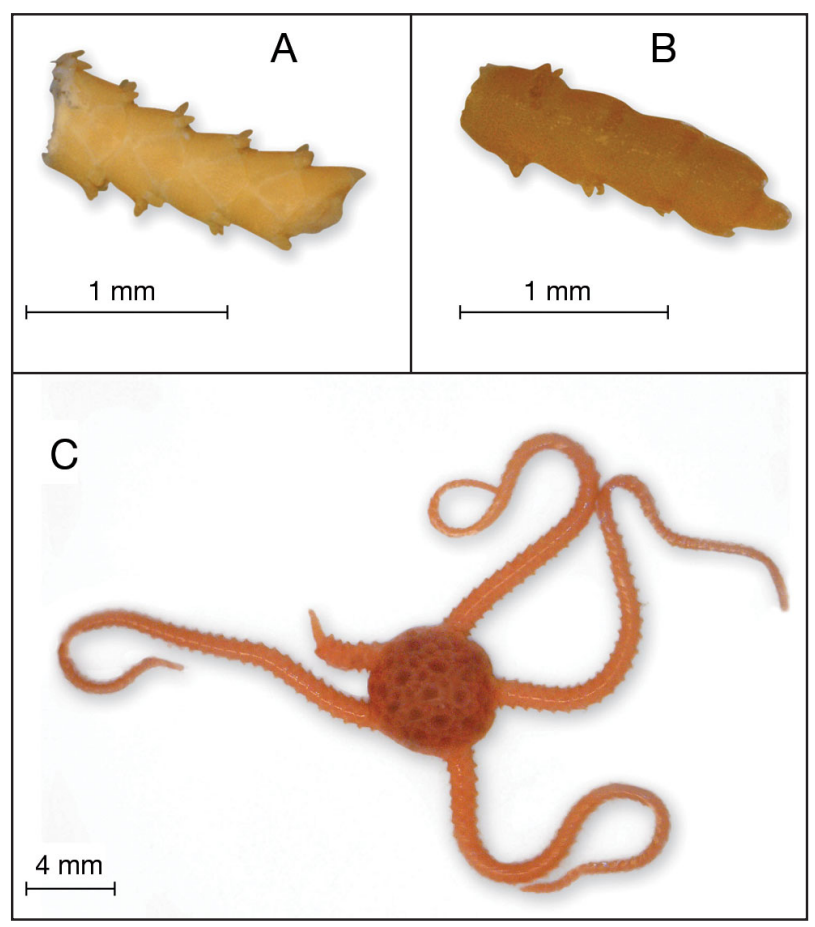

Fig. 4. Ophiura crassa. Brittle star arm regeneration at (A) 5 mo, (B) 7 mo and (C) 10 mo. Photos: T. Souster, C. Mesher 
an average-sized brittle star has a maximum arm length of $29.6 \mathrm{~mm}$, this re-growth rate of $0.16 \mathrm{~mm} \mathrm{mo}^{-1}$ (ca. $2 \mathrm{~mm} \mathrm{yr}^{-1}$ ) could mean that the full regeneration of an arm could take a considerable number of years (Table 2). The arm regeneration data are log:linear in form, indicating that the rate of regeneration did increase over the period of the experiment. Hence, the exact time scale for full arm regeneration is difficult to accurately predict. The regeneration period in this study was at a time when the aquarium temperatures increased from $-1.1^{\circ} \mathrm{C}$ (November) to $+1.9^{\circ} \mathrm{C}$ (March), so temperature might have played a role in rate variability, but there are other potential influencing factors. For example, growth rates of echinoderms are highly dependent on food availability and quality (Lawrence \& Lane 1982, McClintock et al. 1988, Brey et al. 1995, Brockington et al. 2001), which is further complicated in the Antarctic by an extreme seasonality in primary productivity (Clarke \& Leakey 1996). Whilst the brittle stars in this study were held from late in the austral summer 2010, after the phytoplankton bloom, through to the following midsummer of 2011, encompassing the most productive periods, it is not possible to retrospectively assess nutritional history or seasonal effects, especially as their food is likely to be of benthic origin.

Previous analyses of regeneration rates and temperatures for different species of brittle stars showed a significant correlation ( $p<$ 0.01 ) between temperature and regeneration rate (Table 2, Clark et al. 2007). However, the slowest arm regeneration rate prior to this study has recently been described in the temperate brittle star Ophioderma longicaudum at $0.177 \mathrm{~mm} \mathrm{wk}^{-1}$ (Biressi et al. 2010). Whilst the regeneration rate of Ophiura crassa at $0.04 \mathrm{~mm} \mathrm{wk}^{-1}$ initially appears to be much slower, calculating the $Q_{10}$ between these 2 species produces a $Q_{10}=2.5$, which is what would be expected for a temperature effect on normal systems. Hence, arm regeneration in these 2 species proceeds at a similar rate taking account of temperature once regeneration is underway. The very slow regeneration in $O$. longicaudum was proposed as a representative feature of this family (Ophiodermatidae). However, this is clearly no longer the case (Table 2). One interesting point is

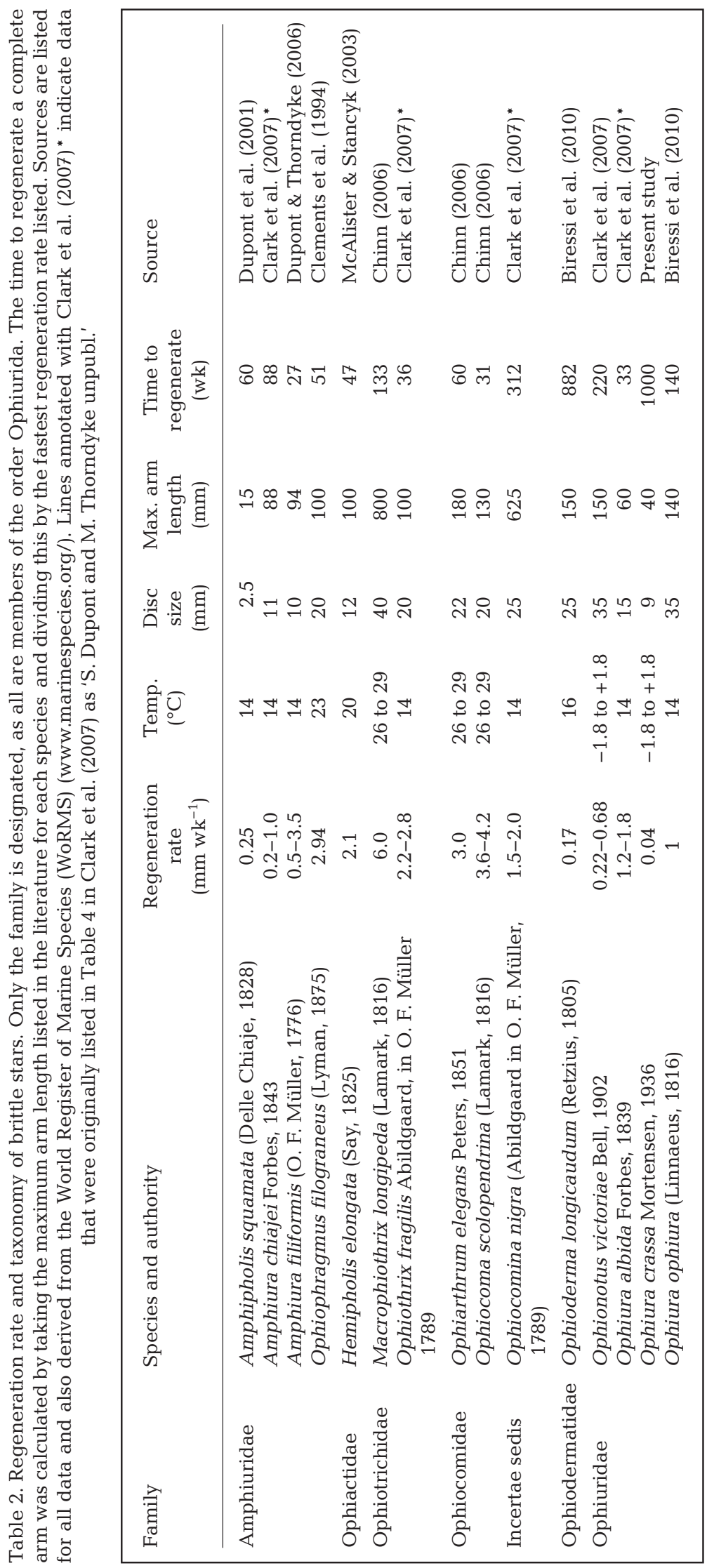


that $O$. longicaudum and $O$. crassa have very different habitat requirements and life histories. The former lives in shallow waters ( 0 to $70 \mathrm{~m}$ depth), is carnivorous and has a disc diameter of 1 to $3 \mathrm{~cm}$ (Tortonese 1965), whilst O. crassa has been found down to $220 \mathrm{~m}$, is a detritivore and has a disc diameter of 4 to $10 \mathrm{~mm}$ (Table 1). In size, habit and ecology, O. crassa is much more similar to the comparator species in the Biressi et al. (2010) study, Amphiura filiformis, which regenerates very quickly. This illustrates the difficulty in comparing regeneration rates between brittle star species, and perhaps a better measure is how long it takes to regenerate a whole arm in each species. Using this criterion, both $O$. crassa and $O$. longicaudum still take a very long time (Table 2). The time scales represented in Table 2 are only estimates (and probably maximum estimates) as arm regeneration is complex. The times to regenerate a new arm given in Table 2 are calculated for whole arms of the oldest animals, which almost certainly will be a very rare event in the natural environment. However, it is another way of demonstrating time scales for the brittle star arm regeneration process. Some species regenerate arms at different rates, depending on how much of the arm was amputated (Dupont \& Thorndyke 2006), age, nutritional and reproductive status, which are highly influential, (Bowmer \& Keegan 1983) and skeleton to tissue ratios, which may also change as the arms mature and develop full functionality (Stancyk et al. 1994). Some studies have used dry weight and ash-free dry weight ratios of re-growing arms to disc weights as a different metric to assess arm regeneration processes, but there are problems with this approach as disc weights can vary by a factor of 4 depending on reproductive status, and the previous factors, stated above, also apply (Bowmer \& Keegan 1983).

Although there are still very few examples of brittle stars showing extremely slow regeneration (1 in a temperate region, 2 in the Antarctic), there is no obvious ecological or physiological factor linking all 3 that could potentially hold the key to understanding why the rate should be so slow in these contrasting species or why the initial regeneration phases are so pronounced in Antarctic species. Whilst histological analyses can identify cell types involved in the regeneration processes (Biressi et al. 2010), molecular analyses can potentially offer more fine-scale insights, not just into particular biochemical and signalling pathways (Bannister et al. 2005, Burns et al. 2011), but they may also generate a more general overview with large-scale Expressed Sequence Tag (EST) projects (Ortiz-Pineda et al. 2009) and the application of next-generation sequencing technologies. Indeed, such technologies may be essential to identifying why regeneration is so slow in these species.

Acknowledgements. This paper was produced within the British Antarctic Survey (BAS) Polar Sciences for Planet Earth Programme, Adaptations and Physiology group. The authors thank all members of the Rothera Dive Team for collecting specimens. Overall diving support was provided by the National Environment Research Council National Facility for Scientific Diving at Oban. The authors also thank S. Morley for statistical advice and L. Peck for statistical and more general advice, including ecological observations, plus R. Martin-Ledo for identifying the brittle stars and J. Oliver in the BAS public relations department for helping produce Fig. 4. We also thank 4 anonymous reviewers who greatly improved the manuscript.

\section{LITERATURE CITED}

Arnaud PM, Lopez CM, Olaso I, Ramil F, Ramos-Espla AA, Ramos A (1998) Semi-quantitative study of macrobenthic fauna in the region of the South Shetland Islands and the Antarctic Peninsula. Polar Biol 19:160-166

Bannister R, McGonnell IM, Graham A, Thorndyke MC, Beesley PW (2005) Afuni, a novel transforming growth factor-beta gene is involved in arm regeneration by the brittle star Amphiura filiformis. Dev Genes Evol 215: 393-401

> Biressi A, Zou T, Dupont S, Dahlberg C and others (2010) Wound healing and arm regeneration in Ophioderma longicaudum and Amphiura filiformis (Ophiuroidea, Echinodermata): comparative morphogenesis and histogenesis. Zoomorphology 129:1-19

$>$ Bourgoin A, Guillou M (1994) Arm regeneration in two populations of Acronida brachiata (Montagu) (Echinodermata: Ophiuroidea) in Douarnenez Bay, (Brittany: France): an ecological significance. J Exp Mar Biol Ecol 184:123-139

> Bowmer T, Keegan BF (1983) Field survey of the occurrence and significance of regeneration in Amphiura filiformis (Echinodermata: Ophiuroidea) from Galway Bay, west coast of Ireland. Mar Biol 74:65-71

Brey T, Pearse J, Basch L, McClintock J, Slattery M (1995) Growth and production of Sterechinus neumayeri (Echinoidea: Echinodermata) in McMurdo Sound, Antarctica. Mar Biol 124:279-292

> Brockington S, Clarke A, Chapman A (2001) Seasonality of feeding and nutritional status during the austral winter in the Antarctic sea urchin Sterechinus neumayeri. Mar Biol 139:127-138

> Brown KM, Fraser KPP, Barnes DKA, Peck LS (2004) Links between the structure of an Antarctic shallow-water community and ice-scour frequency. Oecologia 141: $121-129$

Burns G, Ortega-Martinez O, Thorndyke MC, Peck LS, Dupont S, Clark MS (2011) Dynamic gene expression profiles during arm regeneration in the brittle star Amphiura. J Exp Mar Biol Ecol 407:315-322

> Casaux R, Barrera-Oro E, Baroni A, Ramón A (2003) Ecology of inshore notothenioid fish from the Danco Coast, Antarctic Peninsula. Polar Biol 26:157-165 
Chinn S (2006) Habitat distribution and comparison of the brittle star (Echinodermata: Ophiuroidea) arm regeneration on Moorea, French Polynesia. Water Resources Center Archives, Biology and Geomorphology of Tropical Islands (ESPM 017/1B 158). University of California, Berkeley, CA

Clark MS, Dupont S, Rossetti H, Burns G, Thorndyke MC, Peck LS (2007) Delayed arm regeneration in the Antarctic brittle star Ophionotus victoriae. Aquat Biol 1:45-53

Clarke A (1983) Life in cold water: the physiological ecology of polar marine ectotherms. Oceanogr Mar Biol Annu Rev 21:341-453

> Clarke A (1988) Seasonality in the antarctic marine environment. Comp Biochem Physiol B Comp Biochem 90: 461-473

Clarke A, Leakey RJG (1996) The seasonal cycle of phytoplankton, macronutrients, and the microbial community in a nearshore Antarctic marine ecosystem. Limnol Oceanogr 41:1281-1294

> Clements LAJ, Bell SS, Kurdziel JP (1994) Abundance and arm loss of the infaunal brittlestar Ophiophragmus filograneus (Echinodermata, Ophiuroidea), with an experimental determination of regeneration rates in natural and planted seagrass beds. Mar Biol 121:97-104

> Dahm C, Brey T (1998) Determination of growth and age of slow growing brittle stars (Echinodermata: Ophiuroidea) from natural growth bands. J Mar Biol Assoc UK 78: 941-951

Dupont S, Thorndyke MC (2006) Growth or differentiation? Adaptive regeneration in the brittlestar Amphiura filiformis. J Exp Biol 209:3873-3881

Dupont S, Vangeluwe D, Mallefet J (2001) Arm regeneration in the luminous ophiuroid Amphipholis squamata: a functional approach. In: Barker M (ed) Echinoderms 2000. Swets \& Zeitlinger, Lisse, p 255-259

Fratt DB, Dearborn JH (1984) Feeding biology of the Antarctic brittle star Ophionotus victoriae (Echinodermata, Ophiuroidea). Polar Biol 3:127-139

Grange LJ, Tyler PA, Peck LS, Cornelius N (2004) Long-term interannual cycles of the gametogenic ecology of the Antarctic brittle star Ophionotus victoriae. Mar Ecol Prog Ser 278:141-155

Johnston EL, Connell SD, Irving AD, Pile AJ, Gillanders BM (2007) Antarctic patterns of shallow subtidal habitat and inhabitants in Wilke's Land. Polar Biol 30:781-788

Lane A, Riddle MJ (2004) Toxicity of dispersed and undispersed diesel in sediments to the Antarctic ophiuroid Ophiura crassa. Aust J Ecotoxicol 10:115-121

Lawrence JM, Lane JM (1982) The utilisation of nutrients by post-metamorphic echinoderms. In: Jangoux M, Lawrence JM (eds) Echinoderm nutrition. A. A. Balkema, Rotterdam, p 311-372

Madsen FJ (1967) Ophiuroidea. British and Australian New Zealand Antarctic Research Expedition 1929-1931. Rep

Editorial responsibility: Mike Thorndyke,

Fiskebäckskil, Sweden
Adelaide Ser B Zool Bot 9:123-145

McAlister JS, Stancyk SE (2003) Effects of variable water motion on regeneration of Hemipholis elongata (Echinodermata, Ophiuroidea). Invertebr Biol 122:166-176

> McClintock JB (1994) Trophic biology of antarctic shallowwater echinoderms. Mar Ecol Prog Ser 111:191-202

McClintock JB, Pearse JS, Bosch I (1988) Population structure and energetics of the shallow-water antarctic sea star Odontaster validus in contrasting habitats. Mar Biol 99:235-246

McKnight DG (1967) Echinoderms from Cape Hallett, Ross Sea. N Z J Mar Freshw Res 1:314-323

Medeiros-Bergen DE, Ebert TA (1995) Growth, fecundity and mortality rates of two intertidal brittle stars (Echinodermata: Ophiuroidea) with contrasting modes of development. J Exp Mar Biol Ecol 189:47-64

Mortensen TH (1936) Echinoidea and Ophiuridea. In: Discovery Reports XII, National Institute of Oceanography, Cambridge, p 199-348

Moya F, Ramos A, Manjón-Cabeza ME (2003) Distribution and ecology of Ophionotus victoriae Bell, 1902 (Ophiuroidea, Echinodermata) in the South Shetland Islands area (Antarctica). Bol Inst Esp Oceanogr 19:49-55

> Munday BW (1993) Field survey of the occurrence and significance of regeneration in Amphiura chiajei (Echinodermata, Ophiuroidea) from Killary Harbour, west coast of Ireland. Mar Biol 115:661-668

Ortiz-Pineda PA, Ramírez-Gómez F, Pérez-Ortiz J, González-Díaz S and others (2009) Gene expression profiling of intestinal regeneration in the sea cucumber. BMC Genomics 10:262

Pearse JS, McClintock JB, Bosch I (1991) Reproduction of antarctic benthic marine invertebrates: tempos, modes, and timing. Am Zool 31:65-80

> Peck LS (2005) Prospects for survival in the Southern Ocean: vulnerability of benthic species to temperature change. Antarct Sci 17:497-507

> Peck LS, Convey P, Barnes DKA (2006) Environmental constraints on life histories in Antarctic ecosystems: tempos, timings and predictability. Biol Rev Camb Philos Soc 81: 75-109

> Sköld M, Rosenberg R (1996) Arm regeneration frequency in eight species of Ophiuroidea (Echinodermata) from European sea areas. J Sea Res 35:353-362

> Stancyk SE, Golde HM, Papelindstrom PA, Dobson WE (1994) Born to lose. 1. Measures of tissue loss and regeneration by the brittlestar Microphiopholis gracillima (Echinodermata, Ophiuroidea). Mar Biol 118:451-462

Stewart B (1996) Sub-lethal predation and rate of regeneration in the euryalinid snake star Astrobrachion constrictum (Echinodermata, Ophiuroidea) in a New Zealand fiord. J Exp Mar Biol Ecol 199:269-283

Tortonese E (1965) Fauna d'Italia, Vol 6: Echinodermata. Calderoni, Bologna

Submitted: June 10, 2011; Accepted: April 2, 2012

Proofs received from author(s): June 14, 2012 